telescope near Riyadh. The maintenance and operation of the telescope would be undertaken by British scientists, for the first few years at least. The proposal was prompted by a BBC overseas broadcast, "Science and Industry", in which Sir Bernard Lovell said that no new telescopes had been built for eight years. In October, Sir Richard Woolley, the Astronomer Royal, is visiting Riyadh as a guest of the vicerector to look into the possibilities of the project. Until the new university at Jeddah opens, the University of Riyadh is the only one in Saudi Arabia with science faculties. A department of astronomy was set up this year, under the direction of Mr Robert Seeds, a British lecturer.

\section{The More we are Together}

THRe bodies which represent chemists in Britain are contemplating amalgamation. The Chemical Society, the Royal Institute of Chemistry and the Society of Chemical Industry have agreed that an independent investigation should be undertaken with a view to making recommendations about amalgamation. Sir Eric Bingen, a former Deputy Chairman of Imperial Chemical Industries, Ltd., is to carry out the investigation. His first task will be to assess the work done by each of the societies, and to work out ways in which the essential activities of each may be maintained within an organization incorporating all three. His report will be complete by the end of the year, and each of the societies will be taking it with them to their annual conferences in the spring of 1968.

The idea of amalgamation has been talked about for many years (see Nature, 214, 335; 1967). Casting envious eyes at the American Chemical Society, previous presidents of the British societies have felt that British chemists might be better represented by a larger society on the American model. The functions of the American Chemical Society are in Britain carried out by half a dozen different societies, none of which alone can truly be said to represent chemists. The Royal Institute and the Chemical Society already have some joint activities; together they publish Chemistry in Britain, and their annual conference next year in Dublin will be a joint affair. At the local level, the three bodies hold joint meetings, and it is not uncommon for officials to overlap between the societies, holding local office in one society one year, and in another the next. With a combined society of 40,000 chemists, it is felt, better representation and perhaps administrative savings would be possible.

The latest move towards amalgamation seems to have been the joint inspiration of the three presidents. Sir Harry Melville, President of the Chemical Society, sparked it off in a recent speech, and since then has met $\mathrm{Mr}$ N. A. Iliff, President of the SCI, and Mr I. H. Williams, President of the RIC, for talks. Sir Eric Bingen was selected for the task of bringing the three societies together because of his success in an equally delicate operation, organizing the amalgamation of the Association of British Chemical Manufacturers and the Association of Chemical and Allied Employers into the Chemical Industries Association. How Sir Eric will work is not clear, but he has already had talks with the three organizations. The three presidents are playing their cards close to their chests, and saying nothing.

\section{Paper Productivity}

Whole the United States engages in doctorate production (Nature, 215, 805; 1967), India seems to concern itself with the "productivity of publications". This is one of the section headings in a report issued by the Indian Council of Scientific and Industrial Research in its "Occasional Papers Series", entitled Scientific Research in India; an Analysis of Publications, by Dr B. V. Rangarao. It appears that 10 or 12 scientist years are required to produce one Indian paper. By far the biggest output of papers came from the universities, with 3,800 out of the 9,800 published in all of India in 1965. Top of the paper production league is the University of Calcutta, with 279 papers, closely followed by Agra University (260). The report does not actually name the unproductive laboratories; it merely observes that "though there are a large number of research units in the country, the activity is serious only in a small number of them", and warns that "it may be worth studying the per capita publication in different organizations".

Medicine is the subject of most Indian papers: indeed, of the 64 papers from the University of Patna, 44 were in medicine. By contrast, workers on electric traction, thermoelectricity and clectric lights are completely uncommunicative. The report bemoans this, but gives no account of how many people there are either to produce the papers or to read them. Team work, Dr Rangarao continues, is of the essence; most papers published in the advanced countries are by two joint authors, but in India the rule still seems to be one man one paper. "Even in the technological universities, where team work should be easy to organize, the average authorship is only $1 \cdot 6$. This aspect requires some critical analysis ..."

The report is somewhat at a loss to explain the low output of scientific papers in India. The thirteen most prolific universities were neither the oldest nor were they better endowed. The best explanation seems, therefore, to be that Indian scientists are uninterested in interdisciplinary activity and prefer to work alone. Cure this, and paper productivity and average authorship will no doubt rise.

\section{Tropical Aid}

IT seems that the appointment of Dr P. C. Spensley as director of the Tropical Products Institute from March 1967 has been a very good thing for all concerned. The Tropical Research Institute aims to provide sophisticated research which developing countries cannot afford, and technological development work to aid their industrialization programmes. A radical reorganization took place during 1966, so that more emphasis could be placed on food science and technology, industrial economics, industrial engincering and process development. Signs of change are also to be seen in the annual report which was published this week. Instead of giving incomplete progress reports on the year's work for all the current projects, as in the past, the report now includes short monographs that are complete in themselves, on a few selected ones.

The first of these deals with the report on production of protein products from oilseeds for the relief of malnutrition. This report has been written as a guide to 